\title{
Protein kinases in the entomopathogenic fungus Metarhizium anisopliae
}

\author{
Raymond J. St Leger, ${ }^{*}$ Lucille B. Laccetti, Richard C. Staples and Donald W. Roberts
}

Boyce Thompson Institute for Plant Research, Tower Road, Cornell University, Ithaca, New York 14853, USA

(Received 17 October 1989; revised 21 February 1990; accepted 23 March 1990)

\begin{abstract}
Cyclic AMP (cAMP)- and $\mathrm{Ca}^{2+}$-dependent protein kinase activities of the fungus Metarhizium anisopliae were sought in extracts of ungerminated conidia, germinating conidia and mycelium, as well as in purified plasma membranes from mycelium. Ungerminated conidia contained a $\mathrm{Ca}^{2+} /$ calmodulin-dependent protein kinase capable of phosphorylating multiple endogenous proteins and involved in triggering germination. cAMP-dependent protein kinase activity was not detected in ungerminated conidia in spite of the presence of cAMP in these conidia and the pre-germination synthesis of two cAMP-binding proteins. Most phosphorylation events in crude mycelial extracts were $\mathrm{Ca}^{2+}$-dependent but $\mathrm{H}$-series inhibitors of cAMP-dependent kinases selectively repressed phosphorylation of a $27 \mathrm{kDa}$ protein. Plasma membranes from mycelium contained a $\mathrm{Ca}^{2+}$-independent but H-8-sensitive protein kinase with multiple endogenous substrates for phosphorylation. 8-Azido| ${ }^{32}$ P|cAMP bound selectively to a $52 \mathrm{kDa}$ membrane protein indicative of a single cAMP-binding protein. Plasma membranes contained a phosphatase which rapidly ( $<1 \mathrm{~min}$ ) and selectively dephosphorylated a polypeptide of $15 \cdot 5 \mathrm{kDa}$, thus being suited to cause rapid and reversible changes in membrane function. Membranes also contained an adenylate cyclase apparently involved in transmembrane signalling reactions, since mechanical or chemical treatments which stress the fungus caused rapid increases in intracellular levels of cAMP. Reconstitution experiments with a homogenate from a crisp-1 mutant of Neurospora crassa suggested G-protein regulation of Metarhizium plasmalemma adenylate cyclase.
\end{abstract}

\section{Introduction}

Conidia of the entomopathogenic fungus Metarhizium anisopliae attach, swell and form a germ-tube upon contact with an insect host. The germling then develops an appressorium from which an infection peg eventually penetrates the cuticle. A recent study has demonstrated that while water and a variety of nutrients allow germination, more specific thigmotropic and chemical stimuli are required for appressorium formation (St Leger et al., 1989a). The pathway of signal transduction has not been defined.

The biochemical basis of transduction of extracellular signals has been extensively studied in animal cells, where signalling systems use second messengers such as cAMP and $\mathrm{Ca}^{2+}$ to mediate protein phosphorylation (Cohen, 1982; Nestler et al., 1984). Considerable indirect evidence exists in the literature indicating that cAMP has a parallel role as a second messenger in fungi (Pall,

Abbreviations: CaM, calmodulin; Con A, concanavalin A; Gpp(NH)p, guanyl $5^{\prime}$-imidodiphosphate; SDB(A), Sabouraud dextrose broth (agar); TPA, 12-O-tetradecanoylphorbol-13-acetate; YEM, yeast extract medium.
1981 ; Hoch \& Staples, 1984; Marques et al., 1989). The importance of $\mathrm{Ca}^{2+}$ in fungal growth and development has been known for many years. Also, the occurrence of $\mathrm{CaM}$ in fungi has been well documented (Muthukamar et al., 1987) and studies with $\mathrm{CaM}$ inhibitors suggest a role for $\mathrm{CaM}$ in growth and oosporogenesis of Lagenidium giganteum (Kerwin \& Washino, 1986). Only recently, however, with the isolation of $\mathrm{Ca}^{2+}$ and calmodulin (CaM)-dependent protein kinases from Neurospora crassa (Van Tuinen et al., 1984) and Aspergillus nidulans (Bartelt et al., 1988) has more direct evidence been produced to suggest that $\mathrm{Ca}^{2+}$ has a regulatory role in protein phosphorylation in fungi. In a previous study using intact conidia, we reported decreased incorporation of $\left[{ }^{32} \mathrm{P}\right]$ orthophosphate and $\left[{ }^{35}\right.$ S $]$ methionine into proteins in response to $\mathrm{Ca}^{2+}$ depletion or CaM antagonists (St Leger et al., 1989b). The intact cell phosphorylation approach has many advantages (reviewed by Garrison, 1983) but also the disadvantages that a prolonged incubation with $\left.{ }^{[2} \mathrm{P}\right]$ orthophosphate is required to achieve a constant specific activity of $\left[\gamma_{-32}{ }^{32}\right] A T P$, and that the drugs we used may have had a marked effect on the permeability of the plasma membranes to $\left[{ }^{32} \mathrm{P}\right]$ orthophosphate or on 
the turnover of ATP. At least one CaM antagonist, $N$-(6-aminohexyl)-1-naphthalenesulphonamide (W-5), is not membrane permeable in $M$. anisopliae (unpublished result) and therefore inhibition of nutrient uptake or germination may have been due, at least in part, to membrane stabilization, a side effect of $\mathrm{CaM}$ antagonists which may or may not be mediated by $\mathrm{CaM}$ inhibition (Landry et al., 1981).

In this report we have directly assayed kinase activity in broken cell preparations to confirm that CaM-dependent phosphorylation plays a significant role in the $\mathrm{Ca}^{2+}$ responses associated with germination. Since germination and germ-tube growth are $\mathrm{Ca}^{2+}$-sensitive processes (St Leger et al., 1989b), it is tempting to speculate that transient increases in the concentration of intracellular messengers (e.g. $\mathrm{Ca}^{2+}$ and cAMP) and the activation of protein kinases may be involved in signal transduction between germlings and an inductive surface for appressorial formation. We have used in vitro assay techniques to measure the effects of external stimuli on levels of cAMP and cAMP-binding proteins, and to demonstrate $\mathrm{Ca}^{2+}$-dependent kinase activity in germling cytoplasm. The plasma membrane contains several GTP-binding proteins suited to be coupling factors for transmembrane signal transduction (St Leger et al., 1989c). As critical events in signal transduction probably occur at the plasma membrane, we have investigated phosphorylation of membrane proteins. Data are presented on a $\mathrm{Ca}^{2+}$-independent membrane kinase and its rapid phosphorylation of approximately 40 membrane proteins.

\section{Methods}

Organisms and growth. The fungal isolate (Metarhizium anisopliae $M E 1)$, culture media and germination experiments were as described previously (St Leger et al., 1989a,d). The crisp-1 mutant of Neurospora crassa (C-Ex-11-67) was obtained from the Fungal Genetics Stock Center, University of Kansas Medical Center, USA.

Chemicals. $\left[\alpha^{-32}\right.$ P]ATP, $\left[\gamma^{-32} \mathrm{P}\right] \mathrm{ATP}$ and ${ }^{125}$ I-labelled CaM were obtained from NEN. 8-Azido[ ${ }^{32}$ P]cAMP was from ICN. H-8 was from Seikagaku America Inc. YEM and SDB were from Difco. Other chemicals and 8-hydroxyethylthio-cAMP-beaded agarose were from Sigma.

Preparation of membranes. Plasma membranes were prepared from mycelium by the $\beta$-glucuronidase procedure of Bowman \& Bowman (1988) as described previously (St Leger et al., 1989b). The procedure includes centrifugal washes through EGTA to remove bound $\mathrm{Ca}^{2+}$.

Cyclic AMP content. Cultures were sampled using a $10 \mathrm{ml}$ dispenser, vacuum filtered on $2.1 \mathrm{~cm}$ Whatman GF/A glassfibre filters and dropped into $5 \mathrm{ml}$ ice-cold $5 \%(\mathrm{w} / \mathrm{v})$ trichloroacetic acid (TCA). This process took about $5 \mathrm{~s}$. After $10 \mathrm{~min}$ mycelia were homogenized (1 min) using a motor-driven $(\sim 1100$ r.p.m.) Teflon pestle and extracted for a further $30 \mathrm{~min}$ at $0^{\circ} \mathrm{C}$. The homogenate was centrifuged $(20000 \mathrm{~g}$, $10 \mathrm{~min}, 2^{\circ} \mathrm{C}$ ) and TCA removed from the supernatant solution by extraction with water-saturated diethylether. The ether was removed by heating the solution $\left(100^{\circ} \mathrm{C}, 1 \mathrm{~min}\right)$ and cAMP measured in $50 \mu \mathrm{l}$ of the supernatant with the cyclic AMP assay kit (Amersham).

Washed conidia $(200 \mathrm{mg}$ ) harvested from 10-d-old SDA cultures ( $\mathrm{St}$ Leger et al., 1989b), acid-washed glass beads $(600 \mathrm{mg})(<0.3 \mathrm{~mm}$ diam.) and liquid nitrogen were placed in a $50 \mathrm{ml}$ screwtop centrifuge tube and vortexed for five periods of $5 \mathrm{~min}$ each, with renewal of liquid nitrogen as needed. Rapidly, before the contents of the tube were thawed, the fractured conidia and glass were suspended in $5 \mathrm{ml}$ ice-cold $5 \%$ TCA. All subsequent steps were as described for mycelia.

In control experiments samples of fractured mycelia or conidia treated with phosphodiesterase (beef heart, Sigma) before assay yielded zero values. Addition of cAMP to samples yielded recoveries near $100 \%$.

Photoaffinity labelling with 8-azido[ $\left.{ }^{32} P\right]$ cAMP. Membranes $(0 \cdot 1 \mathrm{mg})$ were added to a reaction mixture containing (final concentration) sodium acetate buffer ( $50 \mathrm{mM}, \mathrm{pH} 4 \cdot 5$ ), 3-isobutyl-1-methyl xanthine (1 mM), BSA $\left(100 \mu \mathrm{g} \mathrm{ml}^{-1}\right)$, PMSF $(50 \mu \mathrm{M})$ and $0.2 \mu \mathrm{M}$-8-azido[32 P]cAMP [specific activity $67.5 \mathrm{Ci} \mathrm{mol}^{-1}\left(2.5 \mathrm{TBq} \mathrm{mol}^{-1}\right)$ ]. After incubating at $4{ }^{\circ} \mathrm{C}$ for $1 \mathrm{~h}$ in the dark the samples were exposed to UV light for $7 \mathrm{~min}$. The reaction was terminated by a 100 -fold dilution with acetate buffer $(50 \mathrm{mM}, \mathrm{pH} 4.5)$ containing BSA $\left(100 \mu \mathrm{g} \mathrm{ml}^{-1}\right)$ and cAMP $(1 \mathrm{mM})$ and the mixture centrifuged $(40 \mathrm{~min}, 108000 \mathrm{~g})$. The pellet was suspended in Laemmli buffer (Laemmli, 1970) by heating at $100^{\circ} \mathrm{C}$ for $3 \mathrm{~min}$ and proteins were separated by SDS-PAGE.

Adenylate cyclase assay. The reaction mixture (final volume $0.1 \mathrm{ml}$ ) contained $100 \mathrm{~mm}$-PIPES, pH 6, $1 \mathrm{mM}$-cAMP, $50 \mathrm{mM}-\mathrm{KCl}, 0.2 \mathrm{~mm}$ 3-isobutyl-1-methylxanthine, $5 \mathrm{~mm}$-phosphoenolpyruvate, $0.02 \mathrm{mg}$ pyruvate kinase, $3 \times 10^{6}$ c.p.m. [ $\left.\alpha{ }^{-32} \mathrm{P}\right] \mathrm{ATP}$ plus the indicated enzyme fractions $(0.05 \mathrm{ml})$ and additions $\left[0.5 \mathrm{~mm}-\mathrm{MnCl}_{2}, 4 \mathrm{mM}-\mathrm{MgCl}_{2}\right.$ or $10 \mu \mathrm{M}-\mathrm{Gpp}(\mathrm{NH}) \mathrm{p}]$. Incubations were at $25^{\circ} \mathrm{C}$ for $30 \mathrm{~min}$ and $\left[\alpha^{32} \mathrm{P}\right] \mathrm{cAMP}$ was purified and assayed according to Salomon $e t$ al. (1974).

Reconstitution of plasma-membrane adenylate cyclase activity. A crude homogenate of a crisp-1 (Cr-1) mutant of Neurospora crassa was prepared in extraction buffer ( 5 mM-PIPES, sodium salt, pH 6.9, $1 \mathrm{mM}$ $\mathrm{MgCl}_{2}, 0.25 \mathrm{~mm}$-EDTA, $1 \mathrm{~mm}$-PMSF, $0.1 \mathrm{~mm}$-leupeptin) by the method of Rosenberg \& Pall (1983). Neurospora homogenate $(4 \mathrm{mg}$ protein $\mathrm{ml}^{-1}$ ) was mixed with an equal volume (total volume $50 \mu \mathrm{l}$ ) of purified Metarhizium plasma membrane ( $1 \mathrm{mg}$ protein $\mathrm{ml}^{-1}$ ) and preincubated at $25^{\circ} \mathrm{C}$ for $15 \mathrm{~min}$ before assaying for adenylate cyclase activity.

In vitro phosphorylation of proteins. Non-differentiated germlings from $20 \mathrm{~h}$ yeast extract cultures (St Leger et al., 1989a) were pulverized under liquid nitrogen. Conidia were vortexed under liquid nitrogen with acid-washed glass beads as described above. Proteins from fractured conidia or germlings were extracted in $50 \mathrm{mM}-\mathrm{Tris} / \mathrm{HCl}$ (pH 7.5) containing CHAPS (10 mM), 2-mercaptoethanol ( $5 \mathrm{mM})$, EGTA (0.5 mM). EDTA (0.5 mM) and PMSF (1 mM). Proteins were washed by ultrafiltration (cut-off $5 \mathrm{kDa}$ ) in $50 \mathrm{~mm}-\mathrm{Tris} / \mathrm{HCl}(\mathrm{pH} \mathrm{7.5})$ containing $1 \mathrm{mM}-\mathrm{PMSF}$. The reaction mixture for assaying protein phosphorylation $(0.1 \mathrm{ml})$ contained $0.2 \mathrm{mg}$ protein, $50 \mathrm{mM}-\mathrm{Tris} / \mathrm{HCl}$ (pH 7.5), $5 \mathrm{~mm}-\mathrm{MgCl}_{2}, 0.5 \mathrm{~mm}-\mathrm{DTT}, 1 \mathrm{~mm}-\mathrm{EGTA}, 0-3.0 \mathrm{mM}-\mathrm{CaCl}_{2}$ and $0.5 \mathrm{nmol}\left[\gamma^{-32}\right.$ P]ATP [ $\left.3000 \mathrm{Ci} \mathrm{mmol}^{-1}\left(111 \mathrm{Tbq} \mathrm{mmol}^{-1}\right)\right]$. Membrane proteins were phosphorylated under similar conditions except that the assay buffer was supplemented with $0.25 \mathrm{M}$-sucrose and in most experiments Triton $\mathrm{X}-100(0.1 \%, \mathrm{w} / \mathrm{v})$ was added to the reaction mixture 15 min before starting the assay (Salimoth \& Marme, 1983). Preliminary experiments showed that pre-incubation with Triton $\mathrm{X}-100$ massively enhanced total phosphorylation of membranes without changing the profile of bands. For phosphorylation, the reaction mixture was pre-incubated for $1 \mathrm{~min}$ at $30^{\circ} \mathrm{C}$ and phosphoryl- 
ation was initiated by adding $\left[\gamma^{-32} \mathrm{P}\right] \mathrm{ATP}$. Incubation was for $3 \mathrm{~min}$ at $30^{\circ} \mathrm{C}$ and the reaction was terminated by adding electrophoresis sample buffer. Phosphorylated polypeptides were analysed by SDS-PAGE and autoradiography as described previously (St Leger $e t$ $a l ., 1989 d)$. Unless stated otherwise, acrylamide concentrations of 8 or $15 \%(\mathrm{w} / \mathrm{v})$ were used to gain maximum resolution for molecular mass estimates of high and low molecular mass polypeptides, respectively.

8-Hydroxyethylthio-cAMP-agarose adsorption. Affinity chromatography was done as described by Marques et al. (1989) and by Weber et al. (1979) with modifications. Conidia germinating in 0.0125\% YEM or YEM supplemented with $2 \%$ sucrose were labelled with [ $\left.{ }^{35} \mathrm{~S}\right] \mathrm{meth}$ ionine as previously described (St Leger et al., 1989d). After $6 \mathrm{~h}$, conidia ( $3 \%$ germination frequency) were collected on a glassfibre disc by vacuum filtration, frozen under liquid nitrogen and lyophilized. Cell extracts were prepared by fracturing conidia as described above and sonicating fragments in $200 \mathrm{~mm}$-MES buffer, $\mathrm{pH} \mathrm{6.2,} \mathrm{containing}$ $0.13 \mathrm{M}-\mathrm{NaF}, 20 \mathrm{mM}$-EDTA, $0.3 \mathrm{mg} \mathrm{BSA} \mathrm{ml} \mathrm{m}^{-1}$ and $1 \mathrm{mM}$-PMSF. The extracts were centrifuged ( 2 min in a Beckman microfuge) and the supernatants incubated with $0.5 \mathrm{ml} 8$-hydroxyethylthio-cAMP-agarose beads for $45 \mathrm{~min}$ at $4{ }^{\circ} \mathrm{C}$ in a final volume of $2 \mathrm{ml}$. The agarose beads were then collected by centrifugation and washed five times, $15 \mathrm{~min}$ each with $1 \mathrm{ml} 10 \mathrm{mM}$-MES buffer, $\mathrm{pH} 6 \cdot 2$, containing $0.1 \mathrm{~mm}$ EDTA, $10 \mathrm{~mm}$-2-mercaptoethanol, $2 \mathrm{M}-\mathrm{NaCl}$ and $1 \mathrm{mM}-5^{\prime}$-AMP to remove non-specifically bound proteins, and washed once for $30 \mathrm{~min}$ with $1 \mathrm{ml} 5 \mathrm{mM}$-MES buffer (pH 6.2), containing $1 \mathrm{mM}-5^{\prime}$-AMP and $1 \mathrm{mM}$-cAMP to remove low-affinity binding proteins. Residual highaffinity proteins were eluted by heating the beads at $100{ }^{\circ} \mathrm{C}$ for $5 \mathrm{~min}$ in the presence of $100 \mu \mathrm{l}$ Laemmli buffer. Following centrifugation, eluted proteins were separated by SDS-PAGE.

Miscellaneous. CaM levels were determined with a CaM-specific radioimmunoassay (RIA) (St Leger et al., 1989b). Proteins were processed for and subjected to SDS-PAGE and Western blots were done as described previously (St Leger et al., 1989d). ${ }^{125}$ I-labelled CaM binding was done by an overlay method after transfer to nitrocellulose as described by Hubbard \& Klee (1987) except that skimmed milk was used as the blocking agent. Staining of glycoproteins with Con A/ peroxidase was done after transfer to nitrocellulose (Faye \& Chrispeels, 1985). Protein concentration was determined by the method of Bradford (1976).

\section{Results}

In vitro phosphorylation of proteins in ungerminated conidia

Approximately 21 radiolabelled proteins were detected when a crude preparation of fractured conidia was incubated in the presence of $\mathrm{Ca}^{2+}$ and $\left[\gamma^{-32} \mathrm{P}\right] \mathrm{ATP}$. Only two phosphoproteins [14.4 kDa (Fig. 1) and $96 \mathrm{kDa}$ (calculated from an $8 \%$ SDS-polyacrylamide gel, data not shown)] were major components of the conidia as determined by Coomassie blue staining. However, five of the more abundant phosphoproteins [34, 39.5, 46 (Fig. 1), 62 and $83 \mathrm{kDa}$ (from an $8 \%$ SDS-polyacrylamide gel, data not shown)] comigrated with Con A/peroxidase stained bands indicating that they might be glycoproteins.

Removal of free $\mathrm{Ca}^{2+}$ by inclusion of EGTA slightly promoted phosphorylation of a low incidence (as determined by Coomassie blue staining) polypeptide $(15 \cdot 2 \mathrm{kDa})$ but severely repressed phosphorylation of other proteins (Fig. 1). The addition of bovine $\mathrm{CaM}$ did not promote phosphorylation over the $\mathrm{Ca}^{2+}$-promoted levels or allow phosphorylation in the absence of $\mathrm{Ca}^{2+}$. The CaM antagonists, R24571 and trifluoroperazine were used to investigate the role of endogenous CaM. R24571 (Fig. 1) and trifluoroperazine (not shown) almost duplicated the effects of EGTA, reducing phosphorylation events except at $15.2 \mathrm{kDa}$. The addition of exogenous bovine $\mathrm{CaM}(15 \mu \mathrm{g})$ to the assay mixture reversed the inhibition caused by R24571 (Fig. 1).

To assess whether other signalling agents might operate in addition to, or substitute for, the $\mathrm{Ca}^{2+1}$ CaM-promoted phosphorylation, a variety of agents were tested for their ability to influence the phosphorylation profile. The addition to the reaction mixtures of TPA $(1-100 \mu \mathrm{M}$; an activator of protein kinase C), cAMP $(5-100 \mu \mathrm{M}), \mathrm{cGMP}(5-100 \mu \mathrm{M}), \mathrm{H}-7$ [10-100 $\mu \mathrm{M}$; the $\mathrm{H}$-series inhibitor with the highest affinity for protein kinase C (Hidaka \& Tanaka, 1987)] and $\mathrm{H}-8$ $[10-100 \mu \mathrm{M}$; the $\mathrm{H}$-series inhibitor with the highest affinity for cyclic-nucleotide-dependent kinases (Hidaka \& Tanaka, 1987)], did not affect phosphorylation of conidial proteins either in the presence or absence of $\mathrm{Ca}^{2+}$ (data not shown).

\section{In vitro phosphorylation of proteins extracted from pre-differentiated germlings}

Approximately 12 and 32 radiolabelled proteins were detected when proteins from $12 \mathrm{~h}$ pre-differentiated germlings were incubated for 1 and $3 \mathrm{~min}$, respectively, in the presence of $\mathrm{Ca}^{2+}$ and $\left[\gamma^{32} \mathrm{P}\right] \mathrm{ATP}$ (Figs 2 and 3). Two phosphoproteins $(25.8$ and $42 \mathrm{kDa})$ were major protein components of the extract. Three of the seven more abundant phosphoproteins $(30,33.7$ and $42 \mathrm{kDa})$ co-migrated with glycoproteins (Fig. 2). A $\mathrm{Ca}^{2+}$-free medium (+EGTA) promoted phosphorylation of a $27 \mathrm{kDa}$ protein but severely repressed phosphorylation of other proteins (Fig. 3). Identical effects by EGTA in the presence of the phosphatase inhibitors sodium molybdate $(5$ or $10 \mathrm{mM})$ and $\mathrm{NaF}(5$ or $10 \mathrm{mM})$ are indicative of an inhibition by EGTA of $\mathrm{Ca}^{2+}$-dependent protein kinase(s) rather than activation of a phosphatase. While cAMP was without effect on total phosphorylation, $\mathrm{H}-7$ and $\mathrm{H}-8$ selectively repressed phosphorylation of the $27 \mathrm{kDa}$ protein (Fig. 3). The addition of TPA, bovine CaM, compound R24571 or cGMP did not affect the profile of protein phosphorylation either in the presence or absence of $\mathrm{Ca}^{2+}$ (Fig. 3 or not shown). 


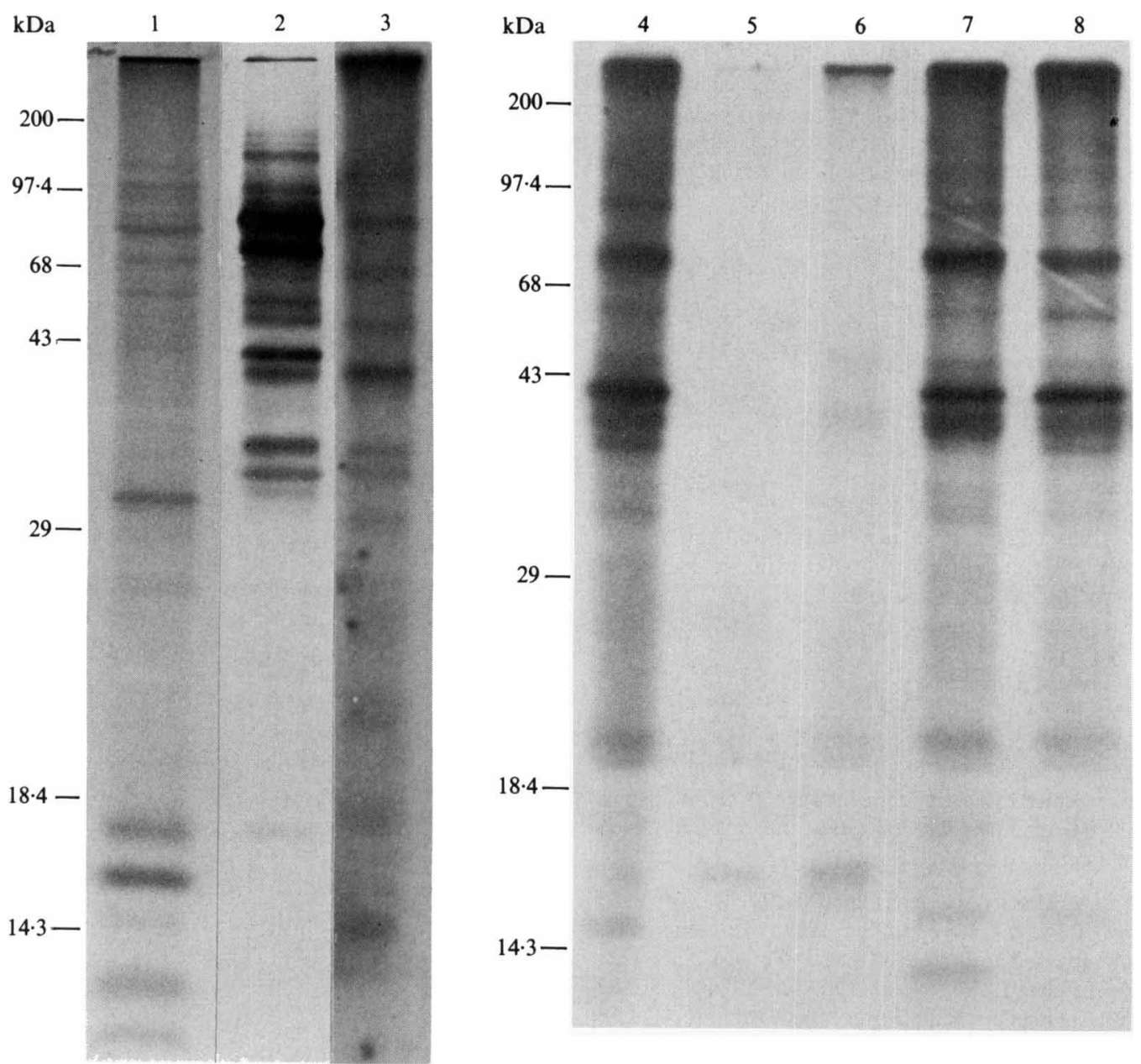

Fig. 1. SDS-PAGE analysis of Metarhizium conidial proteins. Lane 1, conidial proteins stained with Coomassie blue dye; lane 2, glycoproteins detected by binding of Con A to proteins transferred to nitrocellulose membranes. The other lanes are autoradiographs of conidial proteins phosphorylated in the presence of $\left[\gamma-{ }^{32} \mathrm{P}\right] \mathrm{ATP}$ for $1 \mathrm{~min}$ (lane 3); for $3 \mathrm{~min}$ in the presence of $0 \cdot 2 \mathrm{mM}^{-\mathrm{Ca}^{2+}}\left(+\mathrm{Ca}^{2+}\right)$ (lane 4); in the presence of $2 \mathrm{mM}-\mathrm{EGTA}\left(-\mathrm{Ca}^{2+}\right.$ ) (lane 5); of $0.2 \mathrm{mM}-\mathrm{Ca}^{2+}+5 \mu \mathrm{M}-\mathrm{R} 24571$ (lane 6); of $0.2 \mathrm{mM}-\mathrm{Ca}^{2+}+5 \mu \mathrm{M}-$ $\mathrm{R} 24571+15 \mu \mathrm{g} \mathrm{CaM}$ (lane 7); or of $0 \cdot 2 \mathrm{mM}-\mathrm{Ca}^{2+}+20 \mu \mathrm{M} \mathrm{H}-8$ (lane 8).

\section{In vitro phosphorylation of membrane proteins}

Plasma membranes contained both kinase activity and at least 40 endogenous substrates. The predominant $52 \mathrm{kDa}$ band is a major component of the membrane as determined by Coomassie blue staining (Fig. 4). The $52 \mathrm{kDa}$ band and four other phosphoproteins (36, 38,40 and $41.5 \mathrm{kDa}$ ) comigrated with glycoproteins (Fig. 4).

Proteins in the plasma membrane were phosphorylated in $\mathrm{Ca}^{2+}$ and $\mathrm{CaM}$-independent reactions (Fig. 4). Although cAMP $(1-50 \mu \mathrm{M})$ did not increase phosphorylation, millimolar levels of cAMP strongly inhibited total phosphorylation. Also, $\mathrm{H}-7$ and $\mathrm{H}-8$ inhibited the bulk of membrane phosphorylation at $10 \mu \mathrm{M}$ and $5 \mu \mathrm{M}$ concen- trations, respectively. $\mathrm{H}-8(5 \mu \mathrm{M})$ was sometimes effective at suppressing phosphorylation of the major $52 \mathrm{kDa}$ band; $15 \mu \mathrm{M}$ was effective on each occasion (five replicates). H-8 was without effect on a minor (as determined by Coomassie blue staining) polypeptide (15.5 kDa) (Fig. 5).

The ${ }^{32} \mathrm{P}$ incorporation observed in Figs 4 and 5 may represent net phosphorylation resulting from protein kinase and phosphatase activity. To demonstrate phosphatase activity membranes were incubated with $\left[\gamma^{-32} \mathrm{P}\right] \mathrm{ATP}$ for $1 \mathrm{~min}$ and then chased with nonradioactive ATP in the presence of $25 \mu \mathrm{M}-\mathrm{H}-8$ (Fig. 6). The $15.5 \mathrm{kDa}$ phosphoprotein was rapidly $(<1 \mathrm{~min})$ and specifically dephosphorylated indicative of a selective membrane-bound phosphoprotein phosphatase. 


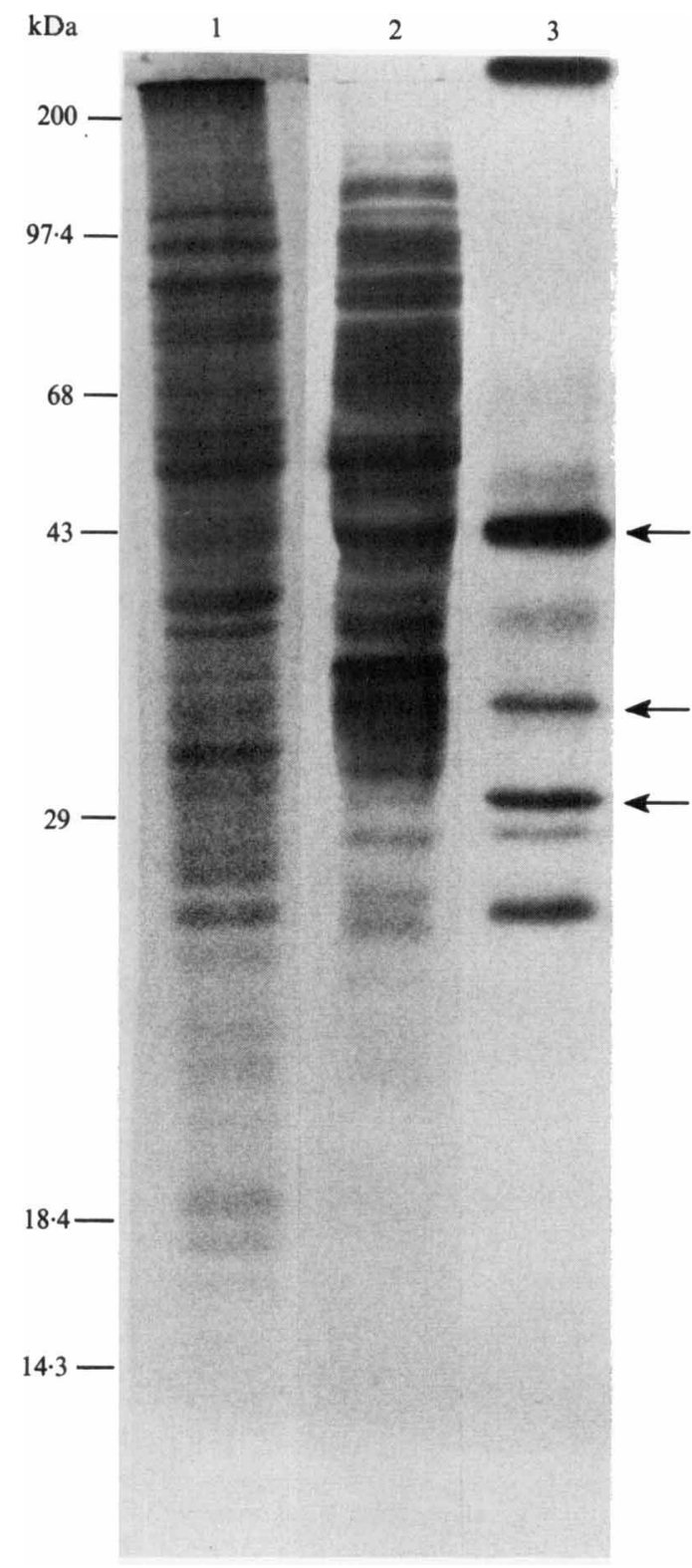

Fig. 2. SDS-PAGE analysis of soluble proteins extracted from germlings of Metarhizium. Lane 1, germling proteins stained with Coomassie blue dye; lane 2, glycoproteins detected by binding of Con A to proteins transferred to nitrocellulose membranes; lane 3, autoradiograph of germling proteins phosphorylated in the presence of $\left[\gamma^{32} \mathrm{P}\right]$ ATP for $1 \mathrm{~min}$. Arrows indicate phosphoproteins which comigrated with glycoproteins.

\section{8-Azido $\left[{ }^{32} P\right] c A M P$ labelling of a $c A M P$-binding protein in plasma membranes}

Use of the photoaffinity analogue of cAMP, 8-azido$\left.{ }^{32} \mathrm{P}\right] \mathrm{cAMP}$, demonstrated one major high-affinity cAMP-binding protein in the plasma membrane accompanied by several additional faint bands on either side. The major band had the same molecular mass
$(52 \mathrm{kDa})$ as the protein which was phosphorylated most intensively with $\left[\gamma^{-32} \mathrm{P}\right] A T P$ (Fig. 7). The 8-azido[32 P]cAMP-labelled band represents a specific cAMPbinding protein since adding unlabelled cAMP $(0 \cdot 1 \mathrm{mM})$ to the reaction mixture prior to irradiation prevented incorporation of radioactivity (Fig. 7), whereas $0.2 \mathrm{~mm}$ cGMP, AMP, ATP or GTP did not prevent labelling (Fig. 7 or data not shown).

\section{Adenylate cyclase activity in Metarhizium membranes}

Metarhizium membranes had adenylate cyclase activity in assay mixtures containing $\mathbf{M n}^{2+}$ but not in mixtures containing $\mathrm{Mg}^{2+}$ (Table 1). Activities were not influenced by the stable GTP analogue $\mathrm{Gpp}(\mathrm{NH}) \mathrm{p} . \mathrm{Mg}^{2+}$ dependent and $\mathrm{Gpp}(\mathrm{NH}) \mathrm{p}$-sensitive adenylate cyclase activity were observed when Metarhizium membranes were reconstituted with a homogenate of Cr-1 Neurospora crassa defective in the adenylate cyclase catalytic component but not in a GTP-sensitive regulatory component (Rosenberg \& Pall, 1983). Thus, the regulatory component in the $\mathrm{Cr}-1$ extract can impart $\mathbf{M g}^{2+}$ and GTP sensitivity to the catalytic unit in Metarhizium plasma membranes.

\section{Quantification of cAMP and demonstration of second messenger target proteins in Metarhizium}

Using biotinylated $\mathrm{CaM}$ we previously demonstrated the presence of CaM-binding proteins in conidia and mycelia (St Leger et al., 1989b). ${ }^{125}$ I-labelled CaM binding confirmed the presence of CaM-target proteins in the preparations of conidia and mycelia used for phosphorylation assays. The membrane preparation, however, possessed only trace levels of one ${ }^{125}$ I-labelled CaM-binding protein (Fig. 8). CaM levels in membranes and conidial and mycelial preparations were $<0.05$, $2.5 \pm 0.31$ and $1.8 \pm 0.30 \mu \mathrm{g}(\mathrm{mg} \text { total protein })^{-1}$, respectively ( $n=5$ independent measurements).

cAMP levels in extracts from conidia and mycelia were $0.4 \pm 0.08$ and $1.1 \pm 0.06 \mathrm{pmol}(\mathrm{mg}$ dry wt fungus) $)^{-1}$, respectively. Levels of cAMP in plasma membranes were low [about $0.4 \pm 0.02 \mathrm{pmol}$ (mg dry wt $)^{-1}$ ] compared with mycelia. Similar levels of cAMP were found in mycelia grown for periods up to $2 \mathrm{~h}$ in nutrient-limiting conditions $(0.005 \%$ YEM) or in nutrient-rich media (YEM supplemented with 2\% sucrose). Stressing the fungus, however, by drying mycelia from $30 \mathrm{~h}$ SDB cultures for $5 \mathrm{~min}$ in a laminar flow cupboard or chilling for $1 \mathrm{~min}$ by adding ice-cold media (final temperature $12^{\circ} \mathrm{C}$ ) increased levels of cAMP from $1 \cdot 1 \pm 0.12$ to $2.3 \pm 0.43$ and $3.2 \pm 0.47 \mathrm{pmol}$ (mg dry wt) $)^{-1}$, respectively ( $n=5$ independent measure- 

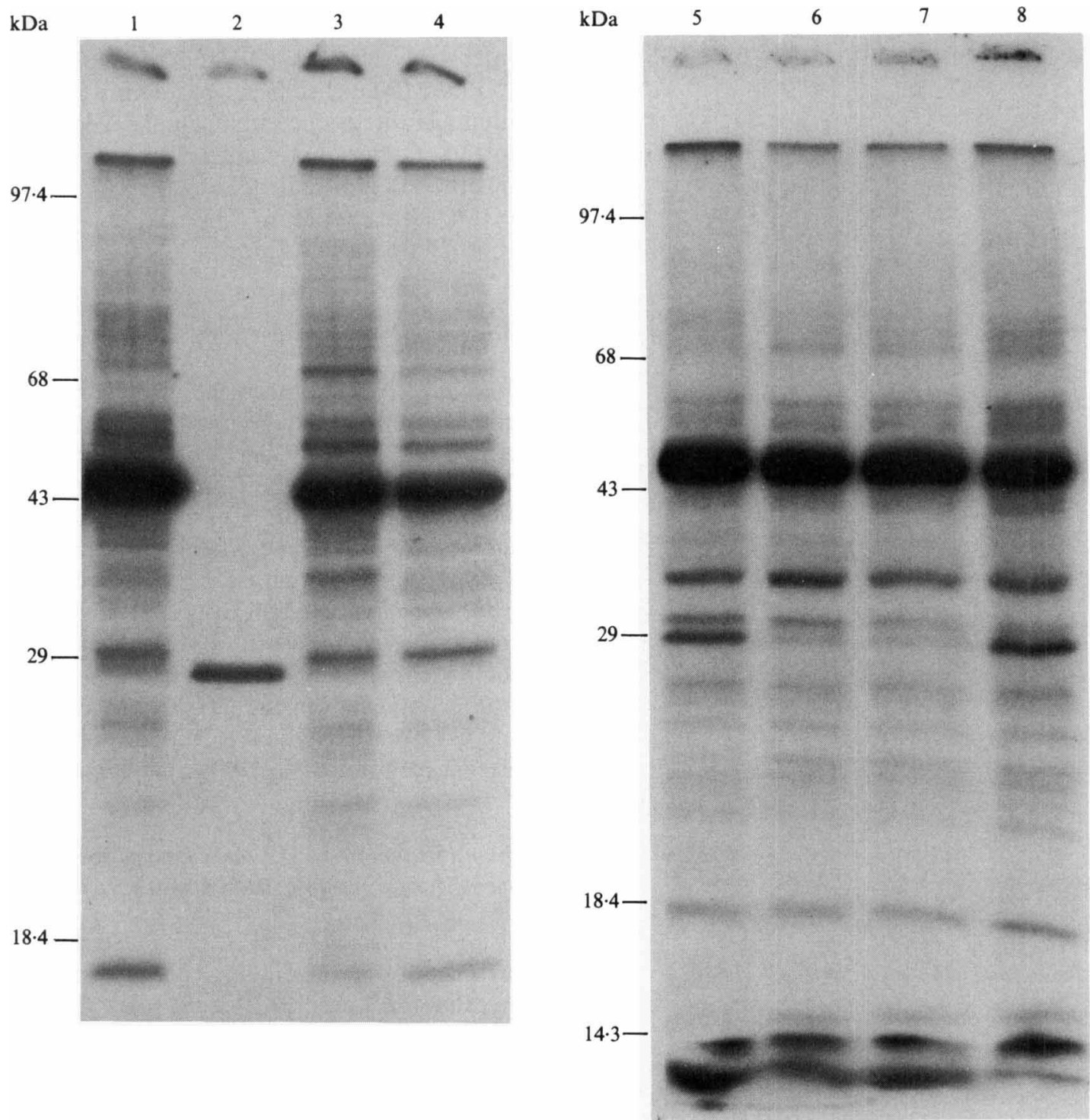

Fig. 3. Cofactor dependence of phosphorylation of soluble proteins extracted from germlings of Metarhizium. Proteins were phosphorylated for 3 min with $\left[\gamma^{-32} \mathrm{P}\right] \mathrm{ATP}$ in the presence of : $0 \cdot 2 \mathrm{mM}-\mathrm{Ca}^{2+}\left(+\mathrm{Ca}^{2+}\right)\left(\right.$ lanes 1 and 5); $2 \mathrm{mM}-\mathrm{EGTA}\left(-\mathrm{Ca}^{2+}\right)(\mathrm{lane} 2)$; 0.1 mM-TPA (lane 3); $10 \mathrm{mM}-\mathrm{NaF}+10 \mathrm{mM}$-sodium molybdate (lane 4); $0 \cdot 2 \mathrm{mM}-\mathrm{CaCl}_{2}+5 \mu \mathrm{M}-\mathrm{H}-8$ (lane 6); $0 \cdot 2 \mathrm{mM}-\mathrm{CaCl} \mathrm{C}_{2}+15 \mu \mathrm{M}-\mathrm{H}-7$ (lane 7); $0.2 \mathrm{mM}-\mathrm{CaCl}_{2}+20 \mu \mathrm{M}$-cAMP (lane 8). Proteins were subjected to SDS-PAGE followed by autoradiography.

ments). The elevation of cAMP levels induced by chilling was transitory, normal levels returning within $15 \mathrm{~min}$. Drying, however, produced a more prolonged increase in cAMP $\left[2.8 \pm 0.17 \mathrm{pmol}(\mathrm{mg} \text { dry } \mathrm{wt})^{-1}\right.$ after $15 \mathrm{~min}$. Adding the membrane-depolarizing agent polymyxin B $\left(50 \mu \mathrm{ml}^{-1}\right)$ to $30 \mathrm{~h}$ SDB cultures elevated cAMP 2.3-fold [2.5 \pm 0.26 pmol (mg dry wt $\left.)^{-1}, n=5\right]$ which declined to normal levels within $15 \mathrm{~min}$.

The synthesis of high-affinity cAMP-binding proteins $(16.2$ and $36.3 \mathrm{kDa})$ during germination was demonstrated by SDS-PAGE of labelled conidial extracts absorbed to the affinity substrate 8-hydroxyethylthio-
cAMP-agarose (Fig. 9). The data also show that production of these proteins was constitutive as it occurred irrespective of levels of sucrose in media capable of repressing catabolite-controlled enzymes (St Leger et al., 1988). Stressing the fungus by adding polymyxin B did not affect the profile of labelled cAMPbinding proteins in mycelia (data not shown).

\section{Discussion}

We report the occurrence of a $\mathrm{Ca}^{2+} / \mathrm{CaM}$-dependent protein kinase capable of multiple phosphoryl- 


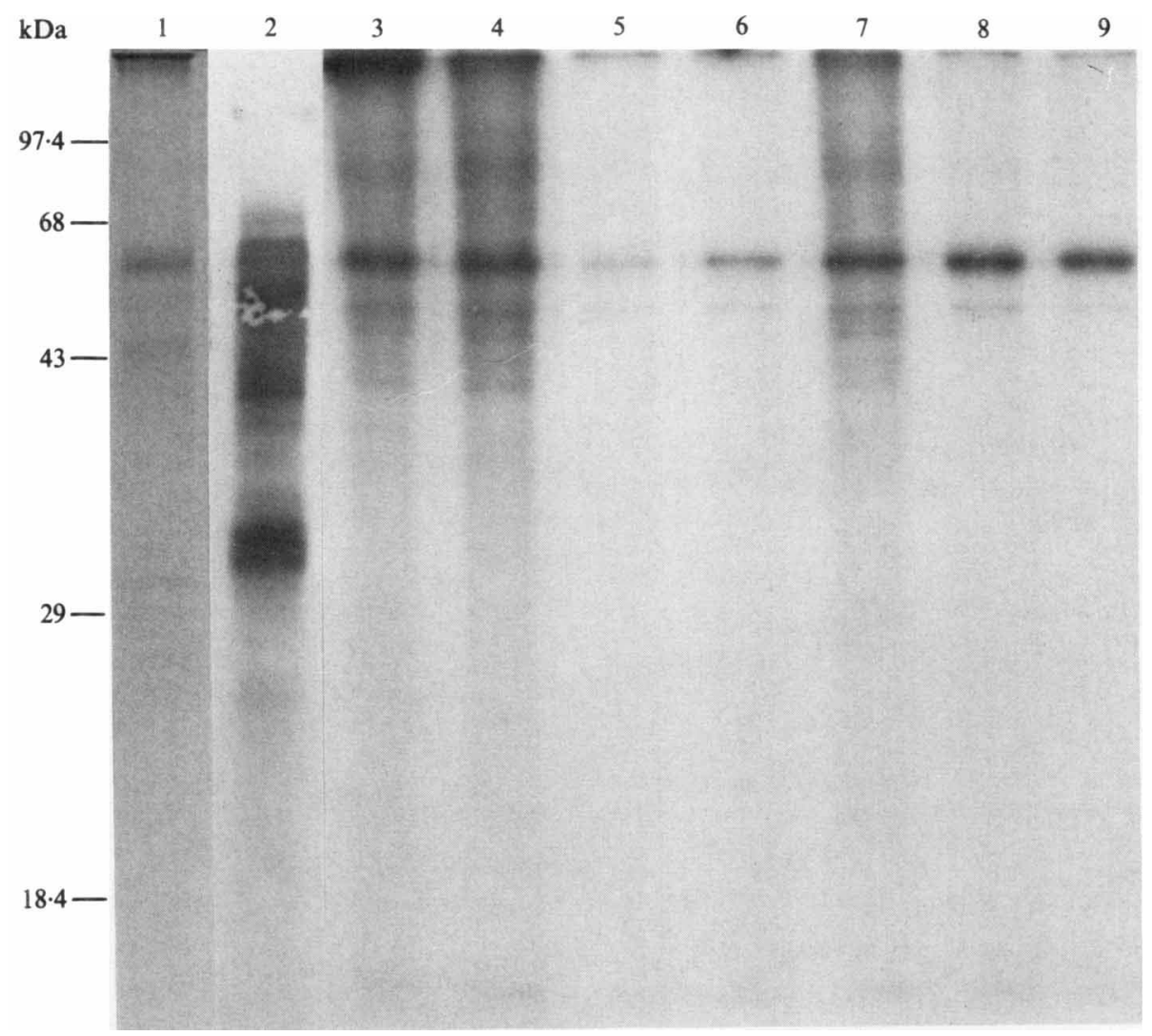

Fig. 4. SDS-PAGE $(12 \%, \mathrm{w} / \mathrm{v}$, acrylamide $)$ analysis of Metarhizium plasma membrane proteins. Lane 1 , membrane proteins stained with Coomassie blue dye; lane 2, glycoproteins detected by binding of Con A to proteins transferred to nitrocellulose membranes. The other lanes are autoradiographs of membrane proteins phosphorylated with $\left[\gamma^{-32} \mathrm{P}\right] \mathrm{ATP}$ for $3 \mathrm{~min}$ in the presence of : $0.2 \mathrm{mM}-\mathrm{Ca}^{2+}$ $\left(+\mathrm{Ca}^{2+}\right)$ (lane 3); 2 mM-EGTA $\left(-\mathrm{Ca}^{2+}\right)+5 \mu \mathrm{M}-\mathrm{R} 24571$ (lane 4); 0.2 $\mathrm{mM}^{2} \mathrm{Ca}^{2+}+2$ mM-cAMP (lane 5); 2 mM-EGTA + 2 mM-cAMP (lane 6); 0.2 mM-Ca ${ }^{2+}+30 \mu \mathrm{M}-\mathrm{cAMP}$ (lane 7); 0.2 mM-Ca ${ }^{2+}+15 \mu \mathrm{M}-\mathrm{H}-7$ (lane 8); $0 \cdot 2 \mathrm{mM}^{2} \mathrm{Ca}^{2+}+5 \mu \mathrm{M}-\mathrm{H}-8$ (lane 9).

ation events in ungerminated conidia of Metarhizium anisopliae. These results corroborate previous findings from in vivo labelling experiments (St Leger et al., 1989b), and provide strong evidence that a $\mathrm{Ca}^{2+} / \mathrm{CaM}$-dependent kinase serves to modulate the effects of $\mathrm{Ca}^{2+}$ on the system which triggers germination. Phosphorylation occurred in the absence of exogenously added CaM but was inhibited by R24571 and trifluoperazine, indicating that endogenous levels of CaM (about $0.3 \%$ of total protein; St Leger et al., 1989b) are not limiting to conidial phosphorylation events. The presence of CaMtarget proteins in conidia also implies that at least some elements required for $\mathrm{Ca}^{2+}$ activation of germination events are constitutive.

Although $\mathrm{Ca}^{2+}$ has been implicated in a variety of responses in other fungi (Jackson \& Heath, 1989) the present results provide the first direct evidence of a role for $\mathrm{Ca}^{2+} / \mathrm{CaM}$-dependent phosphorylation in a filamentous fungus.

The apparent absence of any active cAMP-dependent protein phosphorylation distinguishes Metarhizium conidia from conidia of several other fungal species in which germination is triggered by a glucose-induced cAMP-dependent activation of trehalase (Thevelein, 1984). In contrast to glucose, however, nitrogen-sourceinduced trehalose activation is not mediated by cAMP in the yeast Saccharomyces cerevisiae (Thevelein \& Beullens, 1985), which suggests there may be a connection between the regulatory mechanism observed in Metarhizium conidia and their poor germination on glucose as compared with germination on nitrogen sources (St Leger et al., 1989a). The presence of cAMP in ungerminated conidia and the pre-germination synthesis of cAMP-target proteins suggests some role for cAMP after germination is triggered. Apparently, this function is not critical; while the cAMP-dependent kinase inhibitor $\mathrm{H}-8$ specifically repressed phosphorylation of a $27 \mathrm{kDa}$ protein, it had no effect on protein synthesis or germination in YEM (St Leger et al., 1989b).

The phosphorylation of Metarhizium membrane proteins is $\mathrm{Ca}^{2-}$-independent, but $\mathrm{Ca}^{2+}$-dependent protein kinase activity is nevertheless a substantial proportion of 


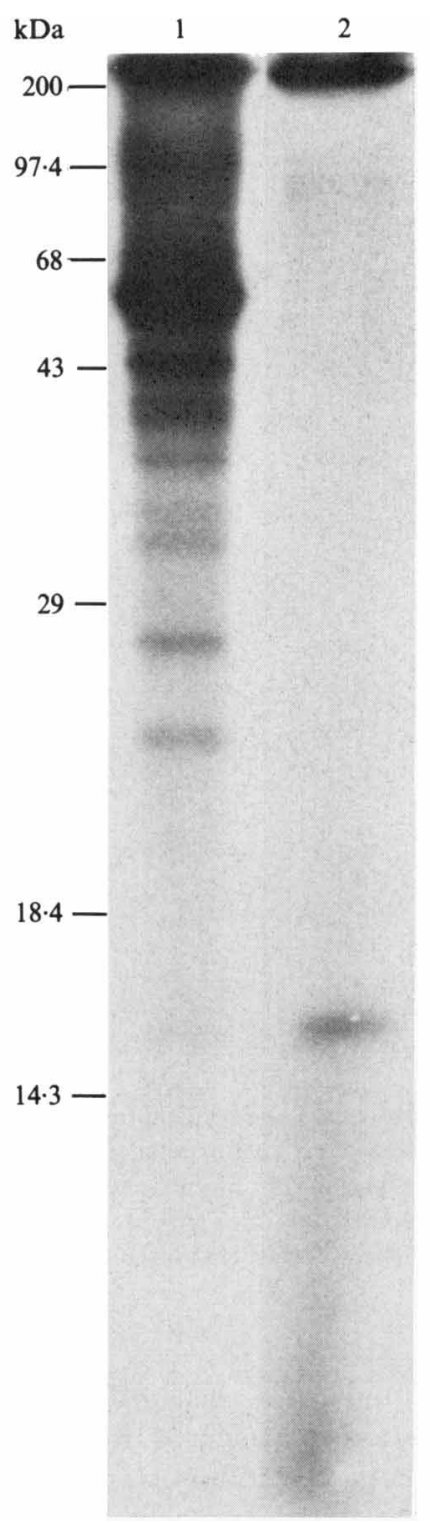

Fig. 5. Phosphorylation of membrane proteins. Proteins were phosphorylated for $2 \mathrm{~min}$ with $\left[\gamma^{32} \mathrm{P}\right] \mathrm{ATP}$ in the presence of $0.2 \mathrm{mM}-\mathrm{Ca}^{2+}$ (lane 1) and 0.2 mM-Ca ${ }^{2+}+50 \mu \mathrm{M}-\mathrm{H}-8$ (lane 2). Proteins were subjected to SDS-PAGE $(15 \%$, w/v, acrylamide) followed by autoradiography.

total activity as assessed using a crude mycelial preparation. A similar situation has been found in some plant systems (Polya et al., 1984). $\mathrm{Ca}^{2+}$ promoted the phosphorylation of polypeptides in crude extract from Metarhizium even in the presence of $\mathrm{CaM}$ antagonists. This suggests that endogenous $\mathrm{CaM}$ was not mediating $\mathrm{Ca}^{2+}$-promoted phosphorylation even though $\mathrm{CaM}$ and CaM-target proteins are present in $M$. anisopliae germlings. The single $\mathrm{Ca}^{2+}$-independent protein phosphorylation event inhibited by $\mathrm{H}$-series inhibitors is presum-

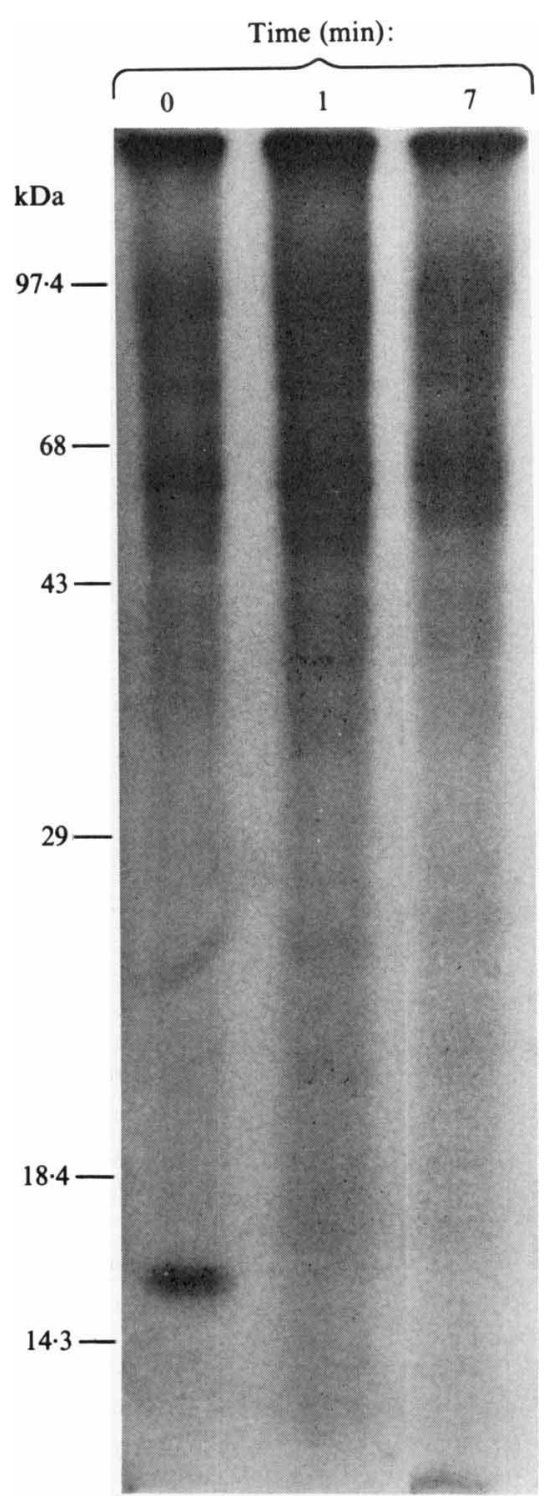

Fig. 6. Phosphatase activity on isolated plasma membranes. Membranes were incubated with $\left[\gamma^{-32} \mathrm{P}\right] \mathrm{ATP}$ for $1 \mathrm{~min}$ (time 0 ) and then chased with cold ATP in the presence of $25 \mu \mathrm{M}-\mathrm{H}-8$ for 1 to $7 \mathrm{~min}$.

ably the same $27 \mathrm{kDa}$ phosphorylated protein identified in vivo and by its sensitivity to $\mathrm{H}-7$ and $\mathrm{H}-8$ (St Leger $e t$ al., $1989 b$ ).

The $\mathrm{Ca}^{2+}$-dependent protein kinase activity was eliminated with the cytoplasmic fraction during isolation of plasma membranes. Membrane phosphorylation occurred in the absence of any effector (e.g. cAMP or $\mathrm{Ca}^{2+}$ ). It is conceivable that the membrane-associated protein kinase was activated prior to or during membrane isolation - in which case cAMP may be the mediator as it is present in the plasma membrane preparation. Inhibition by millimolar levels of cAMP is a 


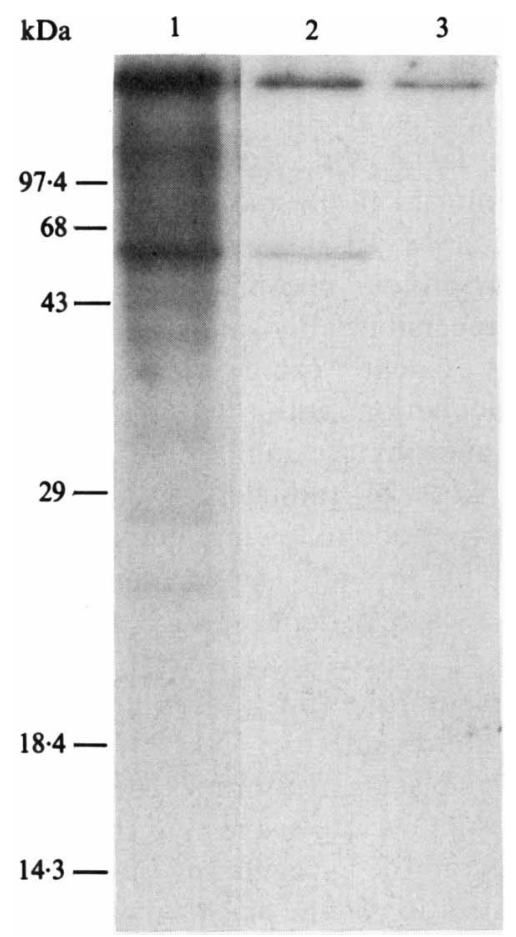

Fig. 7. Phosphorylation of membrane proteins and 8-azido[ ${ }^{32}$ P]cAMP labelling of a cAMP-binding protein in plasma membranes. Lane 1, autoradiograph of membrane proteins phosphorylated with [ $\gamma^{32}$ P]ATP for $3 \mathrm{~min}$. Lanes 2 and 3, 8-Azido[ $\left.{ }^{32} \mathrm{P}\right] \mathrm{cAMP}$ labelling of a $52 \mathrm{kDa}$ protein in the presence of $0.2 \mathrm{mM}$-ATP (lane 2) and $0.1 \mathrm{mM}-$ cAMP (lane 3).

Table 1. Adenylate cyclase activity in plasma-membranes of Metarhizium assayed alone or reconstituted with homogenate of the Cr-1 mutant of Neurospora

The experiment was repeated three times using different preparations of plasmalemma and homogenate, with very similar results.

\begin{tabular}{lcc}
\hline \hline & \multicolumn{2}{c}{$\begin{array}{c}\text { Total activity [pmol cAMP } \\
\left.\min ^{-1}(\mathrm{mg} \text { membrane protein })^{-1} \pm \mathrm{SD}\right]\end{array}$} \\
\cline { 2 - 3 } \multicolumn{1}{c}{ Compound } & $\begin{array}{c}\text { Plasma } \\
\text { membrane }\end{array}$ & $\begin{array}{c}\text { Plasma membrane } \\
+ \text { homogenate }\end{array}$ \\
\hline No addition & 0 & $<0 \cdot 01$ \\
$\mathrm{Mn}^{2+}(0 \cdot 5 \mathrm{mM})$ & $4 \cdot 5 \pm 1 \cdot 1$ & $5 \cdot 2 \pm 1 \cdot 2$ \\
$\mathrm{Mg}^{2+}(4 \mathrm{mM})$ & $<0 \cdot 01$ & $1.8 \pm 0 \cdot 2$ \\
$\mathrm{Mg}^{2+}(4 \mathrm{mM})+$ & $<0.01$ & $5 \cdot 6 \pm 0 \cdot 7$ \\
$\mathrm{Gpp}(\mathrm{NH}) \mathrm{p}(10 \mu \mathrm{M})$ & & \\
\hline \hline
\end{tabular}

* Activity in Neurospora homogenate plus $\mathrm{Mg}^{2+}(4 \mathrm{mM})$ and $\mathrm{Mn}^{2+}$ $(0.5 \mathrm{mM})$ was $<0.01 \mathrm{pmol} \mathrm{cAMP} \mathrm{min}^{-1}(\mathrm{mg} \text { membrane protein })^{-1}$.

characteristic of cAMP-dependent kinases from plasma membranes of animals (Maeno et al., 1974; Müller et al., 1988). The rank order of effectiveness of $\mathrm{H}$-series inhibitors of cAMP-dependent phosphorylation ap-

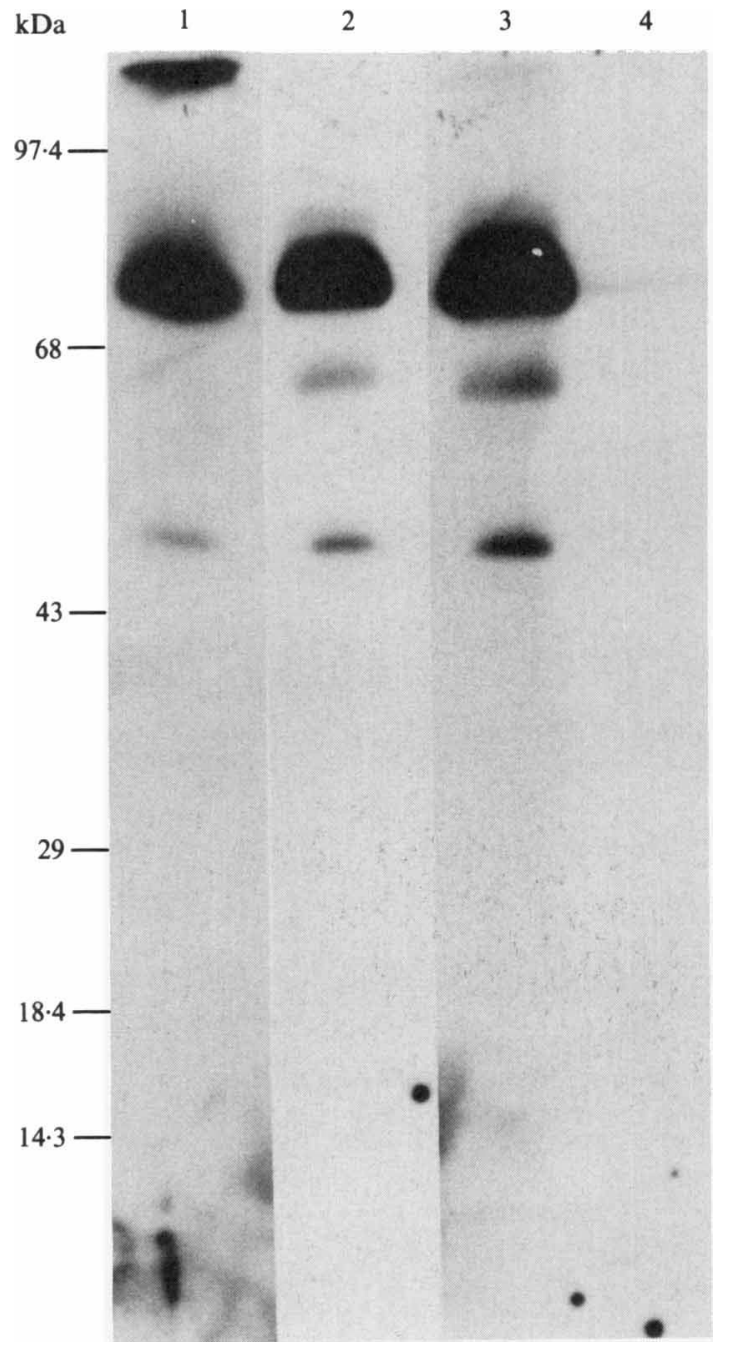

Fig. 8. Detection of CaM-binding proteins by binding of ${ }^{125}$ I-labelled $\mathrm{CaM}$ to proteins transferred to nitrocellulose membranes. Lane 1 , soluble proteins extracted from conidia; lane 2 , total proteins extracted from conidia; lane 3 , soluble proteins extracted from mycelia; lane 4, membrane proteins.

proximated that of their reported binding affinity to cAMP-dependent kinases from other systems $\left[K_{\mathrm{i}}(\mu \mathrm{M})\right.$ values for $\mathrm{H}-7$ and $\mathrm{H}-8$ compared with mammalian cAMP-dependent kinase are 3.0 and 1.2 respectively (Hidaka \& Tanaka, 1987)]. $\mathrm{H}-7$ is also an inhibitor of C-kinase $\left[K_{\mathrm{i}}(\mu \mathrm{M})=6\right.$ (Hidaka \& Tanaka, 1987)] but the $\mathrm{Ca}^{2+}$-independent nature of the reaction and the lack of any effect by TPA makes it very unlikely that a C-kinase is involved.

The major phosphorylated protein in Metarhizium plasma membranes had the same molecular mass $(52 \mathrm{kDa})$ as the putative regulatory subunit of the cAMPdependent kinase which readily bound 8-azido[32P]cAMP indicative of autophosphorylation. The $52 \mathrm{kDa}$ band, and several others, co-migrated with glyco- 


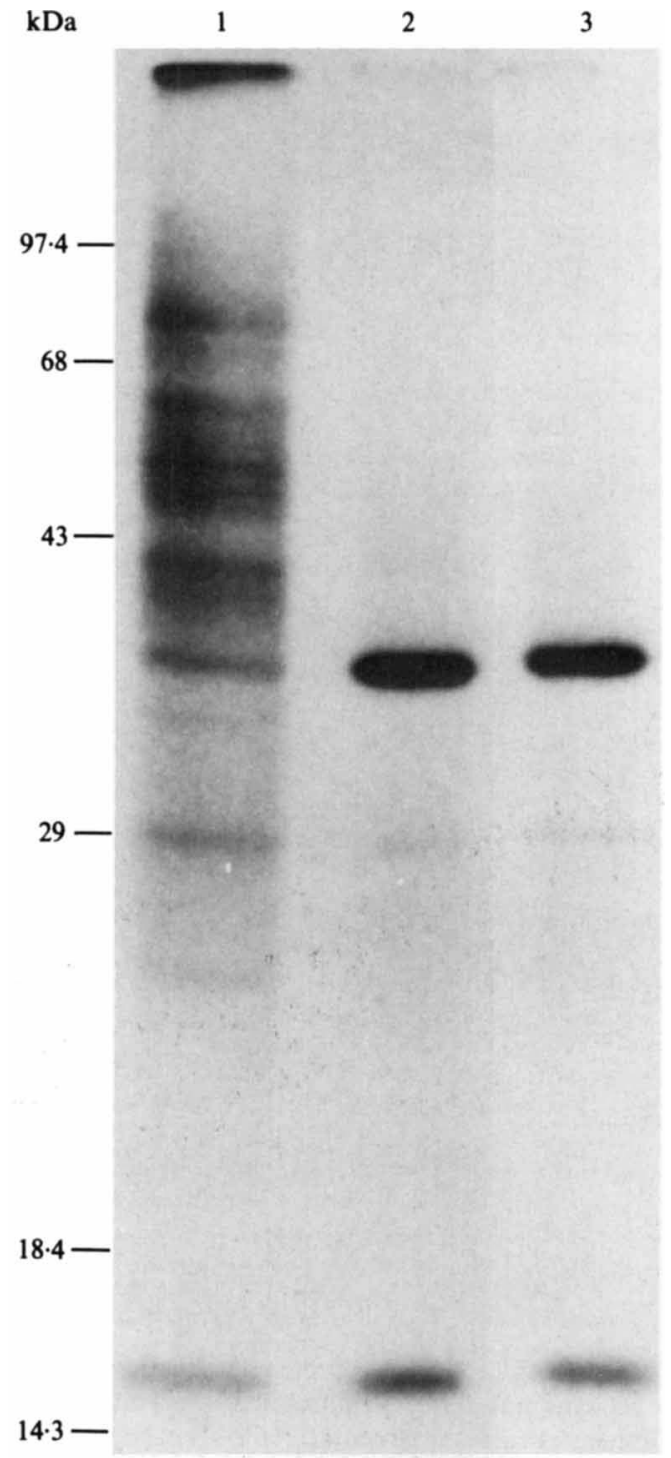

Fig. 9. SDS-PAGE analysis of $\left[{ }^{35}\right.$ S]methionine-labelled conidial extracts adsorbed to 8-hydroxyethylthio-cAMP-agarose. Lane 1, low affinity binding proteins extracted from conidia germinated for $6 \mathrm{~h}$ on $0.0125 \%$ YEM; proteins were released from the gel by washing in 5 mM-MES buffer (pH 6.2) containing 1 mM-5'-AMP and 1 mM-cAMP. Lanes 2 and 3, high-affinity binding proteins from conidia germinated for $6 \mathrm{~h}$ in $0.0125 \%$ YEM (lane 2) or YEM supplemented with $2 \%$ sucrose (lane 3). High-affinity binding proteins were released by boiling the agarose beads ( $5 \mathrm{~min}$ ) in Laemmli buffer (Laemmli, 1970).

\section{References}

Bartelt, D. C., Fidel, S., Farber, L. M., Wolff, D. J. \& Hammell, R. L. (1988). Calmodulin-dependent multifunctional protein kinase in Aspergillus nidulans. Proceedings of the National Academy of Sciences of the United States of America 85, 3279-3283..

BowLES, D. J. (1987). The cell surface in signal transduction: membrane glycoproteins. In The Cell Surface in Signal Transduction, pp. 111-128. Edited by E. Wagner, H. Greppin \& B. Millet. New York: Springer-Verlag. proteins. In mammalian cells, membrane glycoproteins have been implicated in communication networks involving polar signals and $\mathrm{Ca}^{2+}$ mobilization (Bowles, 1987). Little is known about the occurrence of such systems in fungal cell plasma membranes.

To function as an efficient mechanism for signal transduction, protein phosphorylation should be both rapid and reversible. Phosphorylation of membrane proteins was evidently rapid as it was initiated within $1 \mathrm{~min}$ of incubation with $\left[\gamma^{-32} \mathrm{P}\right] \mathrm{ATP}$ and was not affected by phosphatase inhibitors (sodium molybdate and $\mathrm{NaF}$ ). Loss of radioactivity from the labelled $15.5 \mathrm{kDa}$ polypeptide following incubation for $1 \mathrm{~min}$ in unlabelled ATP provides supporting evidence for the existence of a selective dephosphorylating mechanism in the membrane suited to cause rapid and reversible changes of membrane functions which depend on this phosphorylation event.

Metarhizium plasma membranes contain high levels of bound adenylate cyclase suggesting that the membrane plays an integral role in regulating intracellular levels of cAMP. Localization on the plasma membrane implies an involvement in the transfer of extracellular signals to intracellular components. Consistent with this, treatments which can depolarize the plasma membrane or cause mechanical stress produced rapid, usually transient, increases in intracellular cAMP levels, presumably by stimulating the membrane-bound adenylate cyclase(s). Metarhizium membranes contain several GTP-binding proteins suited to be coupling factors for transmembrane signal transduction (St Leger et al., 1989c). Isolated Metarhizium membranes, however, lacked a functional G-component being $\mathrm{Mn}^{2+}$-dependent and insensitive to a stable guanyl nucleotide. The G-component in Neurospora homogenates is highly labile but its activity can be restored by reconstitution with a carefully prepared extract from Cr-1 mutants (Rosenberg \& Pall, 1983). Likewise, adenylate cyclase activity in Metarhizium membranes recognized the regulatory component of a Cr-1 mutant suggesting very similar control of adenylate cyclase activity in the ascomycete Neurospora and the deuteromycete Metarhizium.

This work was supported in part by a grant (89-37263-4463) from the USDA Competitive Research Grants Office.

Bowman, E. J. \& Bowman, B. J. (1988). Purification of vacuolar membrane, mitochondria and plasma membranes from Neurospora crassa and modes of discriminating among the different $\mathrm{H}^{+}$-ATPases. Methods in Enzymology 157, 562-573.

BRADFoRD, M. M. (1976). A rapid and sensitive method for the quantitation of microgram quantities of protein utilizing the principle of protein-dye binding. Analytical Biochemistry 72, 248-254.

CoHEN, P. (1982). The role of protein phosphorylation in neural and hormonal control of cellular activity. Nature, London 296, 613-620. 
FAYe, L. \& ChrisPeels, M. J. (1985). Characterization of N-linked oligosaccharides by affinoblotting with Concanavalin A-peroxidase and treatment of the blots with glycosidases. Analytical Biochemistry 149, 218-224.

GARRISON, J. C. (1983). Measurement of hormone-stimulated protein phosphorylation in intact cells. Methods in Enzymology 99, 20-36.

HidAKA, H. \& TANAKA, T. (1987). Transmembrane $\mathrm{Ca}^{2+}$ signaling and a new class of inhibitors. Methods in Enzymology 139, 570-582.

Hoch, H. C. \& STAPLES, R. C. (1984). Evidence that cAMP initiates nuclear division and infection structure formation in the bean rust fungus Uromyces phaseoli. Experimental Mycology 8, 37-46.

HubBard, M. J. \& KLeE, C. B. (1987). Calmodulin binding by calcineurin. Journal of Biological Chemistry 262, 15062-15070.

JACKSON, S. L. \& HEATH, I. B. (1989). Effects of exogenous calcium ions on tip growth, intracellular $\mathrm{Ca}^{2+}$ concentration and actin arrays in hyphae of the fungus Saprolegnia ferax. Experimental Mycology 13, $1-12$.

Kerwin, J. L. \& Washino, R. K. (1986). Oosporogenesis by Lagenidium giganteum: induction and maturation are regulated by calcium and calmodulin. Canadian Journal of Microbiology 32, 663-672.

LAEMMLI, U. K. (1970). Cleavage of structural proteins during the assembly of the head of bacteriophage T4. Nature, London 227, 680-684.

LANDRY, Y., Amelia, M. \& RuCKstuHL, M. (1981). Can calmodulin inhibitors be used to probe calmodulin effects? Biochemical Pharmacology 30, 2031-2032.

Maeno, H., Reyes, P. L., Ueda, T., RudolPh, S. A. \& Greengard, P. (1974). Autophosphorylation of adenosine 3',5'-monophosphate dependent protein kinase from bovine brain. Archives of Biochemistry and Biophysics 164, 551-559.

Marques, M. V., Juliani, M. H., Maia, J. C. \& Gomes, S. L. (1989). Developmental regulation of expression of the regulatory subunits of the cAMP-dependent protein kinase of Blastocladiella emersonii. European Journal of Biochemistry 178, 803-810.

MülleR, U., Wojna, Z., KöNIG, B. \& SpatZ, H. C. (1988). Thiophosphorylation of the regulatory subunit of the cAMPdependent protein kinase from Drosophila brain tissue. Insect Biochemistry 18, 351-358.

Muthukamar, G., Nickerson, A. W. \& Nickerson, K. W. (1987). Calmodulin levels in yeasts and filamentous fungi. FEMS Microbiology Letters 41, 253-255.

Nestler, E. J., Walaass, S. I. \& Greengard, P. (1984). Neuronal phosphoproteins: physiological and clinical implications. Science 225, 1357-1364.
PalL, M. L. (1981). Adenosine 3', $5^{\prime}$-phosphate in fungi. Microbiological Reviews 45, 462-480.

Polya, G. M., Schibeci, A. \& Micucci, V. (1984). Phosphorylation of membrane proteins from cultured Lolium multiflorum (rye grass) endosperm cells. Plant Science Letters 36, 51-57.

Rosenberg, G. B. \& Pall, M. C. (1983). Reconstitution of adenylate cyclase in Neurospora from two components of the enzyme. Archives of Biochemistry and Biophysics 221, 254-260.

SALIMOTH, B. P. \& MARME, D. (1983). Protein phosphorylation and its regulation by calcium and calmodulin in membrane fractions from Zucchini hypocotyls. Planta 158, 560-568.

SAlomon, Y., Londus, C. \& Rodbell, M. (1974). A highly sensitive adenylate cyclase assay. Analytical Biochemistry 58, 541-548.

St Leger, R. J., Durrands, P. K., CoOper, R. M. \& Charnley, A. K. (1988). Regulation of production of proteolytic enzymes by the entomopathogenic fungus Metarhizium anisopliae. Archives of Microbiology 150, 413-416.

St Leger, R. J., Butt, T. M., Roberts, D. W. \& Staples, R. C. (1989a). Production in vitro of appressoria by the entomopathogenic fungus Metarhizium anisopliae. Experimental Mycology 13, 274-288.

St Leger, R. J., Roberts, D. W. \& Staples, R. C. (1989b). Calciumand calmodulin-mediated protein synthesis and protein phosphorylation during germination, growth and protease production by Metarhizium anisopliae. Journal of General Microbiology 135, 2141-2154.

St Leger, R. J., Roberts, D. W. \& Staples, R. C. (1989c). Novel GTP-binding proteins in plasma membranes of the fungus Metarhizium anisopliae. Biochemical and Biophysical Research Communications 164, 562-566.

St Leger, R. J., Butt, T. M., Staples, R. C. \& Roberts, D. W. $(1989 d)$. Synthesis of proteins including a cuticle degrading protease during differentiation of the entomopathogenic fungus Metarhizium anisopliae. Experimental Mycology 13, 253-262.

TheVelein, J. M. (1984). Regulation of trehalose mobilization in fungi. Microbiological Reviews 48, 42-59.

Thevelein, J. M. \& Beullens, M. (1985). Cyclic AMP and the stimulation of trehalase activity in the yeast Saccharomyces cerevisiae by carbon sources, nitrogen sources and inhibitors of protein synthesis. Journal of General Microbiology 131, 3199-3209.

Van Tuinen, D., Ortega Perez, R., Marmé, D. \& Turian, G. (1984). Calcium calmodulin-dependent protein phosphorylation in Neurospora crassa. FEBS Letters 176, 317-320.

Weber, W., Vogel, C. W. \& Hilz, H. (1979). A new cAMP affinity matrix for the rapid purification of protein kinase regulatory subunits. FEBS Letters 99, 62-66. 